\title{
Innovative Education for Diverse Students in a Changing Era: One U.S. Urban School's Alternative Teaching and Learning
}

\author{
Ming-Hsuan Wu \\ Touro College
}

U. S. A.

ABSTRACT: This critical ethnographic case study describes and interprets how

an urban K-8 charter school in the United States with a large number of students

of color from low-income communities offers education that recognizes

students' minority status in the broader society and envisions students as

agents working toward a just society. The analyses show that the school's progressive teaching of diversity has a positive impact on minority students' identification with their heritages and their academic achievements. This study advances a critical understanding of creating equitable education at the school level.

Challenging Mainstream Discourse on Diversity Role Research Question, Context, Method, and Theoretical Framework Innovative Teaching and Learning at PCCS Understanding Academic Success at PCCS

Conclusion

References

Educational research with a critical lens on schooling has revealed that schools often value and inculcate the cultural and communicative practices of the socially and economically powerful elites, thereby disadvantaging minority students who are not socialized into such practices by their families (Faltis \& Arias, 2013, James, 2012; Ladson-Billings, 2006; Milner, 2013; Ochs \& Schieffelin, 2009; Philips, 2009; Sleeter, 2012). To date, there are still significant gaps in literature for understanding how schools can structure their practices in ways that all students are provided with equal access to educational opportunities. It is within this context that research was conducted with a focus on an urban K-8 charter school with a vision to provide an equitable education for its diverse students. This paper describes and interprets how an urban school serving diverse students from low-income families offers alternative education that exceeds the education typically available for this group of students. Studying a school such as this, in its particular sociopolitical context, can provide the basis for more informed discussions about equitable education in contemporary 
educational contexts. This paper first provides an overview of schools' agentive role in challenging mainstream discourse on diversity. I then offer a brief description of the focal school and research methods. I move to present the observational data and interview excerpts detailing the school's innovative teaching and learning. I conclude with discussion on how the data help us understand alternative approaches promoting academic success among minority students.

\section{Challenging Mainstream Discourse on Diversity: Schools' Agentive Role}

Diversity has often been seen as a threat to national unity (Crawford, 2000). The drive for homogeneity has made schools the key instrument for assimilating minority students into the dominant culture and language (Darder, Baltodano, \& Torres, 2003). To students not from dominant cultural and linguistic backgrounds, schools often provide "subtractive schooling" (Valenzuela, 1999) that does not build upon their knowledge but educate them in ways that correspond to their discriminated social status. Many early ethnographies of schooling (e.g., Heath, 1983) identified the cultural and linguistic dynamics of minority communities, helping to counter the earlier deficit view of minority students and pave the way for subsequent research that highlights the importance of connecting homes and schools. The changing educational response to diversity then focuses on the politics of recognition, which Luke (2009) nicely summarizes as (a) including repressed texts and histories in curriculum; (b) engaging with diverse languages and discourses; (c) expanding school knowledge to include indigenous, traditional, and migrant epistemologies; (d) adjusting cultural patterns of interactive communication, and (e) confronting issues of racism and all forms of discrimination. As linguistic and cultural diversity has become a certainty in current educational settings (cf., Hornberger, 2009), examining various approaches to the politics of recognition provides important insight for educators to engage with diversity in their own contexts. Luke (2009) further argues that different languages and cultures that students bring into the schools are (mis)recognized by those in authority through a set of assumptions and stereotypes about them. Even when those in power assign value to students' cultural and linguistic knowledge in their everyday interactions with students, Luke (2009) foregrounds the potential moments of agency not only for students to challenge how their cultures and languages are interpreted but also for those in authority to unsettle the rules for interpretation. While there are many empirical studies that document individual teachers' or programs' efforts to challenge normative interpretation or ways of interaction through implementing innovative pedagogies that take into account minority students' ways of being and knowing (e.g., Ladson-Billings, 2005; Lucas \& Villegas, 2010; Villegas \& Lucas, 2011), few studies take schools as a unit of analysis to provide an in-depth examination of how schools can provide exemplary educational programs that recognize the political aspects of schooling and attend to their minority students' unique experiences. 
Many charter schools in the United States seek to offer educational alternatives to traditional public schools through unique curricula, culturally relevant pedagogy, and transformative education. Charter schools are public schools operated independently, outside the conventional control of local school districts, with the aim to provide children more opportunities for academic success (Cookson \& Berger, 2002; Murphy \& Shiffman, 2002). Each charter school has its own board of trustees and administrative staff and usually hires its own teachers. As an autonomous educational institution, charter schools make decisions on a wide range of educational issues, including curriculum, textbooks, the length of a school day and school year, and the number and kinds of extracurricular activities. While charter schools are exempt from many educational mandates, they are still subject to the adequate yearly progress (AYP) requirements of the No Child Left Behind law. Charter schools differ from one another according to their missions that reflect their varied foci on community, family, career, cultural heritage, or academic success, and they generally enroll students not through residential assignment but through parents' choices.

Such schools are gaining popularity nationwide since the first charter school opened in 1992. The burgeoning growth of charter schools has triggered considerable educational research and public debate. Advocates argue that charter schools provide innovative educational programs, raise student achievement, offer alternatives to parents, and foster positive competition for traditional public schools (King, 2004; Yancey, 2004). Opponents charge that charter schools have diluted resources that the school districts are entitled to and have promoted racial enclaves within districts (Finn, Manno, \& Vanourek, 2000; Lubienski, 2003 \& 2005). To date, there is still no consistent evidence that charter schools are performing significantly better than traditional public schools (Johnson, 2011; Zimmer, Blanc, Gill, \& Christman, 2008). We need more indepth examination of day-to-day teaching at charter schools to better understand if the unique autonomies that they are afforded lead them to tailor pedagogy to specific populations they serve. This paper reports findings from a study that examines innovative teaching and learning at a charter school serving diverse students from low-income communities. Findings provide implications for educational programs that use minority students' unique experiences as a basis for vigorous academic learning.

\section{Research Question, Context, Method, and Theoretical Framework}

This study set out to describe, interpret, and understand how PCCS (a pseudonym), an urban school that serves culturally, linguistically, and racially diverse students from low-income communities, seeks to offer a type of education that recognizes students' minority status in the broader society and exceeds the education typically available for this group of students. In particular, this research asks the following questions: 
1. How is the school's vision of creating an equitable education for linguistically, culturally, and racially diverse students circulated and enacted in the school policies and pedagogical practices?

2. How do students create and negotiate their identities in the context of school and in response to their experiences in school and the larger society?

Located in a northeastern U.S. city, PCCS is a public K-8 charter school. During the period of the research, about $25 \%$ of its 440 students were receiving or had previously received ESL service, and $90 \%$ were eligible for free and reduced-price lunch. Asian students comprised the largest racial group (70\%) and African American students (20\%) were the second largest. There existed much diversity in the Asian/Asian American population, and the school data disaggregated this population into 13 subgroups. PCCS teachers are as diverse as the student population that they serve. A significant number of the PCCS teachers, paraprofessionals, and administrators are people of color and children of immigrants or immigrants themselves. Growing out of grassroots community efforts to combat the school district's failure of educating immigrant students, PCCS seeks to offer education that does not privilege one type of knowledge over another but engages students in understanding their own cultures. Since its inception in 2005, PCCS students' test scores have increased steadily, and the school achieved AYP for the third consecutive year during my research year.

The primary analytical tool in this study is critical ethnography, an applied form of ethnography with a strong focus on searching for knowledge to inform change (Reason, 2004). The ethnographic researcher's expertise in capturing experiences and perspectives of students and teachers from diverse backgrounds is increasingly recognized as providing important insights for developing sustainable policy and program initiatives (Adair, 2010). While traditional ethnography often analyzes a local community as a complete unit, critical ethnography assumes that practices at the micro-level are inevitably influenced by the macro-level power relations and thus "asks what could be" for future social change to take place (Thomas, 1993, p. 2). During 2010-2011 school year, I spent three full days a week at PCCS engaging in in-depth participant observation, conducting interviews, and collecting relevant school documents. Over time, I shadowed a group of seventh and eighth graders representing diverse linguistic, cultural, and racial backgrounds that more or less reflected student makeup in the school as they attended different classes. I focused on middle school students because they are better able to articulate their educational experiences than elementary school students, and they are also the group of students with whom I had worked for more than two years as a student volunteer at PCCS.

Student interviews were an important part of the study because they allowed for a better understanding of how students perceived their educational experiences at PCCS. To increase students' participation in the interviews, I followed what Foley and Valenzuela (2005) call a conversational style of interviewing, sharing greater personal information than the conventional 
interview. In many student interviews, questions only roughly guided the conversations, which often were intertwined with casual conversations at a more personal level. Observational data and interview transcripts went through an iterative process of open coding, initial memos, focused coding, and integrative memos (Creswell, 2013; Maxwell, 2013; Miles, Huberman \& Saldana, 2013).

In understanding minority students' experiences and their potential to foster social change, this research study draws on educational research from a critical pedagogy perspective (CP) that situates the historical struggles of people of color in the context of social justice and aims to create social change by engaging with minority students in critique of the social realities in which they are living (Alim, 2007; Luke, 2009). It is through reflecting upon their everyday experiences that students learn about decoding texts and the complexity of social relationships. As students learn to recognize asymmetrical relations of power that determine the structure they are living in, they also develop intellectual capacities and social skills necessary for them to feel empowered to make social changes (Alim, 2010; Darder, 2014). In other words, CP combines a "language of critique" with a "language of possibility" in the attempt to create social justice (Giroux, 1989). The "language of possibility" recognizes the need to explore new alternatives in the quest of improvement of our societies and helps develop a new ethic suitable for our multicultural and transnational communities.

Important to the discussion of knowledge production in school and society is how history is taught to students. CP theorists argue for the need to attend to what is excluded in the mainstream teaching of history because the dominant explanations often reflect a narrow definition of history that marginalizes knowledge of the oppressed. A CP approach to the teaching of history, therefore, brings in voices of historically oppressed groups, such as women, people of color, and working classes, and delves into students' own histories and systems of meanings (Darder, 2012). Such teaching allows minority students to "name and authenticate their own experiences" and involves them in social transformation (Darder, 2012, p. 85). This study seeks to understand how PCCS teachers and students do and live CP (cf., Wink, 1997) in their particular contexts and how teachers create better educational possibilities for minority students through inclusion of local knowledge.

Research on culturally sustaining pedagogy (Paris, 2012; Paris \& Alim, 2014) also provides important insights to this study. Built upon Ladson-Billings' (1995) work on culturally responsive teaching, Paris and Alim (2014) argue that culturally sustaining pedagogy promotes diversity among students by paying particular attention to the fluid and pluralist nature of youth identity as well as youth cultural practices. In response to current linguistic, cultural, and educational realities of U.S. public schools, culturally sustaining pedagogy highlights the importance of critically addressing issues of culture, equity, and justice and creating room for alternative interpretations of culture as a way to democratize schools. In a similar vein, research in funds of knowledge (González, 2005; Moll, Amanti, Neff, \& González, 1992) seeks to move beyond stereotypical and folkloric representations of the cultural knowledge of minority 
groups to focus on everyday life practices of families. This strand of research explores ways that students' lived experiences can be integrated into a curriculum to create education that surpasses what is generally available for working-class minority students. This paper presents how critical culturally sustaining pedagogy and funds of knowledge offer frameworks to understand PCCS's educational practices for its minority students.

\section{Innovative Teaching and Learning at PCCS}

Based on the analyses of the data, PCCS' unique teaching is summarized as (a) using cultural diversity as a tool for learning; (b) embracing linguistic diversity; (c) attending to students' racialized experiences; and (d) focusing on social justice. I will explore each of these themes in the following section.

\section{Cultural Diversity as a Tool for Learning}

Talking about PCCS teaching has to start with how PCCS views the different cultures students bring to the school. One important part of the PCCS curriculum is teaching folk and traditional arts found within the students' own communities. Folk art is defined as collective art that is practiced for the interests of the community and it exists because the community members have decided that it is important to pass on from one generation to the next (Wei, 2007). Folk art is something that people do out of love for their community. In this sense, forms of self-expression, like graffiti and hip hop, are considered as folk art. PCCS students learn folk arts in the classrooms, after-school programs, and residency. PCCS offers many electives that meet twice a week, as well as afterschool programs, many of which are culturally based, including Dan Tranh (a Vietnamese musical instrument), Chinese lion dance, Batik, hip hop dance, braiding, and African drum and dance. Students are able to enroll in one elective every 12 weeks based on their preferences. Throughout the semester, PCCS also hosts artists who visit different classes and work with the content teachers on certain units. Among the resident artists are a Tibetan Mandala sand painter, an African American storyteller, and a Liberian singer and dancer, to name just a few. It should be noted that many of these artists speak English as a second language and do not have Anglicized names. However, they are all thought of very highly by the PCCS community and are addressed as "Teacher," just as all other adults at PCCS are addressed.

Additionally, all PCCS students have one session of music and one session of art class every week, and both teachers draw teaching materials from students' communities. In the music class, students sing folk songs from representative cultures in their own communities. In a series of art classes that I observed for seventh graders, the art teacher, Teacher Eddie, implemented a proverb documentation project that asked students to go back to their 
communities and interview an adult for proverbs, for which students needed to provide illustrations. He started the unit by discussing proverbs as a genre common to many communities and the metaphoric meanings imbedded in proverbs. Students then were trained to conduct interviews and went back to their communities to document proverbs. The proverbs brought by the students, if not in English, were first translated into English and then grouped by region or culture of origin to highlight their universality, peculiarity, histories, and contexts. After guided analysis of different proverbs, students then made decisions on how to present their proverbs visually in ways that would make sense to viewers from different backgrounds. This project, according to Teacher Eddie, engaged students in developing visual literacy.

By bringing students' cultures into the school's official curriculum, PCCS positions students' cultures and communities as "funds of knowledge" (González, 2005) that have much to offer to all students. Unlike schools that only engage students in learning different cultures periodically and simplistically in multicultural events that end up perpetuating ethnic stereotypes (Lee, 2005; Nieto, 2003), PCCS makes learning about cultural diversity in the students' communities a central part of school curriculum. Such a pedagogical focus creates a learning environment in which many students find their cultures and a sense of who they are validated. An overwhelmingly large number of middle schoolers attributed their positive schooling experience at PCCS to the school's respect for students' cultures and the opportunity to learn about different cultures.

In a group interview on educational experiences at PCCS, two African American seventh graders started out by commenting about their teachers.

Author: So what do you like most about being here?

Romy: They [the teachers] accept our culture and they respect who you are and they don't make fun of who you are.

Levon: Yeah, I like how they are really cultural and accept our culture for who we are.

Both Romy and Levon had attended public schools where, in their own words, teachers there did not like them and therefore they got into trouble often. What made their experiences at PCCS different is related to how teachers here perceived students' cultures: not only do teachers accept students' cultures, but they respect them. It also became clear that both Romy and Levon equated validation of their cultures as validation of their own beings.

In fact, when talking about their educational experiences at PCCS, many PCCS students referenced their time in other public schools that did not seem to respond to students' cultures well. Nick, a Vietnamese American seventh grader, explained,

I think it's [PCCS] better than my old school because the old school they didn't really respect your culture. But here they try and show like a variety of different cultures because they have African dance and Dan Tranh and stuff. It's a mix of different things. 
Before he enrolled in PCCS, Nick, like other immigrant students, had attended inner city public schools, where "the educational climate is often demoralize[ing]" to minority students (Hirschman, 2001, p. 317). In talking about their current experiences at PCCS, Romy, Levon, and Nick, though they had attended different urban public schools, all talked about feeling a sense of isolation and alienation in their previous schools. Many studies have revealed that schools tend to celebrate and privilege White middle-class cultures in their curricula and extracurricular activities; thus, students who are not from this background do not feel welcomed at school, and some even develop distrustful feelings toward teachers or oppositional orientations to schooling (Lee, 2005; Reyes, 2006; Valdés, 1996).

Teaching and learning folk arts and students' cultural traditions seem not only to confirm minority students' sense of selves, but also to help students build interest in and love for different cultures, as evident in the following quote by a Chinese American student:

I like [that] the school has different kinds of teachers, all from different countries, different ethnic backgrounds, and how the school is multilingual and you get to know many cultures, not just one culture.

As one PCCS founder states, teaching different cultures is not about "let me make you feel good about yourself," but about helping students understand the way the rest of the world thinks so they can become a better human being and world citizen (Wei, 2007, p. 240). Ginsberg (2012), who writes about PCCS' folk art curriculum, notes that engaging students in learning their and others' folk arts through active doing and making is important because it moves beyond simplistic constructions of identity based only on one's ethnicity or race. Instead, it helps students start to consider new categories of belonging like "beginners vs. expert, comfortable vs. uneasy, closeness vs. distance." Indeed, one of the best Chinese acrobatics performers was not a Chinese student, but a Vietnamese boy who spent much time practicing it even after the class. Many of those who persisted in this class instead of choosing other electives were African American students. In addition, stepping, with its root in African and African American traditions, was one of the most popular electives among all the students.

\section{Embracing Linguistic Diversity}

Teachers often discuss languages and cultures together in the PCCS community. For example, the school pledge that all students have to recite every morning explicitly states that all people have a right to use their own languages and honor their own cultures. To ensure active communication with the school and the families who speak a wide range of languages, PCCS has multilingual staff and volunteers to translate documents sent back home and offers simultaneous interpretation service in major school events. Driven by the perspective that additive multilingualism is an empowering asset and because of 
the fact that the school is located near the city's Chinatown and Chinese students are the biggest student population, PCSS is the only school in the area that teaches Mandarin to all students. It offers two tracks of Mandarin classes: those with Chinese heritage take Mandarin as a heritage language and those without take it as a foreign language. (See more in-depth discussion of the PCCS Chinese education in Wu, Lee, \& Leung, 2013). PCCS students are also encouraged to maintain and develop knowledge in their heritage languages. Teachers often remind students and parents that all PCCS students should be reading at home every night for 20-30 minutes and that the best way to become a better reader is to read as much as possible in any language. Some students indeed maintain a good command of their heritage languages and are able to translate during cultural electives when the teachers do not speak English. In fact, students' abilities to navigate different linguistic worlds are highly appreciated by PCCS teachers. For instance, the English Language Arts teacher encourages many of her eighth graders to highlight their strengths in their high school application essays as someone who acquired English as an additional language and excelled academically because, as she explains, high schools are looking for kids who work hard and are resilient

PCCS has a well-established ESL program that coordinates closely with content teachers. Due to the large number of ESL students, there are five ESL teachers, who provide ESL students with pull-out instruction in ESL classrooms and often follow ESL students to their content classrooms to offer push-in instruction. According to the ESL teachers, since many students are former ESL students, they could also benefit from teaching practices that are proven helpful for ESL students, such as teaching new vocabulary in context (Nassaji, 2003) and modeling (Herrell, 1999). Therefore, ESL teachers and content teachers coteach the class frequently, which gives ESL teachers an equally important and visible role among the PCCS students. The highly collaborative relations between ESL teachers and the content teachers provide content teachers with good knowledge of their ESL students' progress. Besides, the ESL classrooms are filled with bilingual books and bilingual dictionaries. Since a large number of the ESL students in the upper grades had received their primary education in China, many books are in simplified Chinese. During independent reading time, ESL students from China often pick out these books and read them silently in their seats. Around the walls of the ESL classrooms, one can easily find vocabulary or phrases presented in English alongside another language, usually simplified Chinese and sometimes Spanish, to assist ESL students' understanding.

Although ESL teachers might not be proficient in Mandarin Chinese or Spanish, they often rely on Google translation to provide key vocabulary and phrases in students' first languages. It is worth mentioning that the presentation of Chinese characters does not simply serve as a comprehension aid for these students to learn English; it becomes a review device for them to maintain their Chinese literacy skills to some extent. Several older ESL students from China often practiced character writing and reading when they saw the ESL teachers put up the Chinese-English bilingual vocabulary cards. They also talked about 
how well (or poorly) the Chinese Google translation captured the essence of the vocabulary. Interestingly, many also lamented how many Chinese characters they had forgotten since they had arrived in the United States because they were reading and writing in Chinese far less than before. The availability of bilingual books and vocabulary cards, coupled with a supportive language learning environment, seems to enable PCCS' ESL students, particularly those with some Chinese literacy, to develop their English proficiency without sacrificing their first languages and their identities.

\section{Attending to Students' Racialized Experiences}

Students at PCCS are predominately students of color from working class backgrounds who are subject to racism in their daily lives. In response to the Eurocentric U.S. mainstream curriculum that fails to validate identities and voices of students from non-dominant groups (Lee, 2005), PCCS makes a concerted effort to teach history or social events from a more critical stance that highlights the experiences of people of color.

The social studies teacher, Teacher Scott, often leads students to interrogate the issues of race in relation to class in some U.S. historical events. For instance, when he taught about the Pennsylvania Line Mutiny during the war with the British, he linked this historical event to students' lives. First, students learned about deplorable conditions for the army and a lack of concern on the part of Continental Congress, which led to mutiny against the Congress that had not paid the soldiers in months. After that, Teacher Scott turned the focus to the present and asked students which part of the city the Army went to in order to recruit high school students. He answered the question himself and told the students that they recruit kids from neighborhoods where a large number of city's poor Blacks and Asians reside. Teacher Scott wanted students to know that "it's not coincidence where they recruit their army" and "Veterans in this country have difficulty getting their money." One African American girl raised her hand to share the story that her family member got annoyed about fighting for veteran paychecks. Teacher Scott added,

Throughout the history of this country, soldiers have been taken advantage of. It's not the wealthy kids that are recruited, but the poor kids. How to recruit them? By promising them something young people don't have. This is still true at this moment. Will Bush's daughter or Obama's daughter serve in the army? Even if they do, they will serve as officer not foot soldiers. (10.6.2010)

PCCS's effort to systematically engage students in thinking about race and racism is further realized in the Courageous Conversations elective for fifth to eighth graders. Taught by an Asian American teacher, Teacher Amy, this elective guides students to learn how people's perceived notions about race influence what one can, or cannot, accomplish through activities. For example, 
Teacher Amy implemented a modified version of Jane Elliot's "Blue Eyes, Brown Eyes" exercise that labeled students as inferior or superior based solely on the color of their eyes and gave them a lesson on discrimination. She randomly assigned students to either the "tall group" or the "short group" and gave contrasting treatments to the two groups. After about five minutes, Teacher Amy had students discuss questions that delved into their feeling and how different treatments are related to racial bias that people of color might experience. Almost all students from both groups noted the negative feelings that came with being in one group, and some students talked about the privileges of being in the other group. Some students mentioned the danger of lumping people together based on heights or skin color. They talked about how not all Asians were good at math and not all Black people were good at sports. Students used their own experiences to offer counter-examples that challenged some widely-held racial stereotypes. While students tended to talk about the racial biases that they knew of from a Black-versus-White lens, Teacher Amy, whenever possible, sought to have students talk about Asian/Asian Americans' experiences. She made the statement, "Race is not just about Black and White in the society," several times during the discussion.

The Courageous Conversation elective also draws students' attention to other social constructs (e.g., gender, ethnicity, and social class), and how they work together to influence individuals' daily perceptions and behaviors. One activity asked students to come up with as many names as possible based on the categories that Teacher Amy created: "People on TV," "models, actors/actresses," "super heroes," "historical figures," "American heroes," "good guys," and "bad guys." After students put the names they wrote on the index cards up on the board according to the categories, she then asked them to rearrange the names based on new sets of categories, including "African American," "Asian," "White," "Latino," "homosexual," and "transgender." When the students were done with the task, Teacher Amy told the students that she was surprised to see the results because when she grew up, she thought that all the famous people were White. She credited PCCS for doing a good job in teaching about diversity. She continued to comment on each new category and the names associated with it. She started with "African American" and noted that only three of the names that the students came up with (Martin Luther King, Jr., Barack Obama, Rosa Park) were not in the entertainment or sports industry. When it came to "Asian," she commented that all of the four people were Chinese males who were either Kungfu masters (Jackie Chan, Jet Li, and Bruce Lee) or a basketball player (Yao Ming). This category had no representation of Southeast Asians. As for the "Latino" category, she brought students' attention to the fact that all of the three names were singers or actresses (Jennifer Lopez, Eva Longoria, and Selena Gomez). She further added that this was the fastest growing population in the United States, and yet we could only think of few ways to represent them. In terms of the "White" group, Teacher Amy thought it was the most diverse group. When Teacher Amy saw that both "homosexual" and "transgender" categories had zero names, she asked students how they might feel if they did not see themselves represented in any media or books. 
With teachers' attempts to bring Asians into the race talk, Asian students learn to see themselves as legitimate citizens in the United States, instead of the "forever foreigner" stereotype that plagues many Asian American communities (Tuan, 1998). The following excerpt from a seventh grade social studies classroom observation shows how Asian American students pushed beyond the normative definition of Americanness to include Asianness in their peer interactions.

Teacher Scott announced the homework for tonight at end of the class.

"Bring an artifact that you think reveals that America is an advanced country," he said. He encouraged students to surprise him tomorrow. Students got excited about what they could bring. An Asian American student Britt told other students that he was going to bring his Buddha jade necklace. A Cambodian American girl Darlene quickly said, "But he [Buddha] is not American." Britt paused for a little bit and then responded, "He is an Asian American. Yes! He is an Asian American."

Britt's decision to bring his Buddha necklace shows his positive identification with his cultural and religious heritage, providing some evidence that PCCS had successfully fulfilled one of its missions, that is, to help students receive affirmation of their languages and cultures. Furthermore, in the context where students were asked to bring something that can represent America, Britt's justification of Buddha as Asian American indicates that he perceived the legitimacy of Asian American culture in contemporary U.S. history. Lastly, Britt's ability to redefine Buddha as Asian American demonstrates his flexible approach to identity construction: one could be both Asian and Asian American, depending on various factors, including the context, the interlocutors, and the individual's will, to name just a few. At a time when many minority students are exposed to a demoralized educational climate that positions them as inferior participants in school, fostering the agency and ability to define a sense of who they are within the context of PCCS might provide them with different prospects as they enter the larger community and society.

\section{Focusing on Social Justice}

PCCS students often receive messages on multiple occasions about their agentive role in shaping the history and the future. One important school event that helps students see individual and collective power in making history is Founders' Day, when students learn about how and why PCCS came to be. Many of the school's founders come to share stories about how seeing unfair treatment of minority students in public schools made them think of making changes. The messages sent to the students highlight the fact that history is always in the making, not necessarily by people with important titles or positions, but by a community of ordinary people working collectively to fight for something important. PCCS students also learn ways that they can practice justice every day, such as making peace with people around them. To become peacemakers 
at school, at home, at the community, and in the society means to become activists who stand up for those in need and those who receive unjust treatment. Students are guided to write down their wishes for peace and reflect upon what they could do to make peace.

The highlight of teaching and learning of peace is a school-wide event called the Peace Concert, during which students perform and display what they have learned in music and art classes and various electives. Songs like "Something Inside So Strong" and "Imagine" are introduced to the students along with their historical contexts (Apartheid South Africa and the Vietnam War). Occasionally, older students are given the freedom and opportunity to compose their own lyrics. During my research year, the eighth graders composed a rap piece entitled "I am a Peacebuilder, I Pledge," in which they reflected upon their roles as peacebuilders who took responsibility for developing a vision of justice. Similar to Teacher Eddie's proverb project that provided a rich context for his students to practice multiple literacies that were not limited to just visual literacy, students in the music class did not just learn to sing or play instruments; they were also developing their critical literacies that helped them understand how power and domination underline and inform the texts (cf., Hull, 1993). A better understanding of sociopolitical-economic contexts of texts and their meanings can lead to an emancipated worldview and transformational social action (McLaren, 1989).

PCCS's commitment to fostering students' critical analysis of texts is evident in what is traditionally known as Columbus Day across the U.S., which celebrates the day Christopher Columbus "discovered" America. As a charter school, PCCS renames this day Many Points of View Day (MPV Day) and engages students with issues related to colonization and representation. For example, students examine Columbus' journals, indigenous peoples' narratives, textbooks, and photographs to reconstruct a more accurate understanding of this history. As students learn that seeing Columbus as a hero is only one point of view, they also start to question what they had learned from textbooks and the media. Teaching students to critically explore Columbus's encounter with America helps students develop critical literacy skills that enable them to see how power often mediates the construction of history. As one teacher explained, MPV Day is about helping PCCS students "grow into thoughtful young adults who can share their points of view with confidence, be open to diverse opinions, and make positive change in the world."

Finally, it should be noted that PCCS's teaching of folk arts practiced in the students' communities as well as bringing students' lived experiences into the classroom is an act of social justice itself. When many minority students continue to receive subtractive schooling that divests them of their languages and cultures and does not provide them with a learning environment for academic success (cf., Valenzuela, 1999), schools are themselves a manifestation of a socially unjust enterprise. Teaching folk arts, particularly in formal school settings, raises critical questions about whose knowledge is legitimate and valued. Below, the art 
teacher explained how his teaching of folk art at PCCS was grounded in social justice.

Giving voices to people who have been marginalized in the United States is a liberatory act. When you share your Cantonese opera that you do with grandma, you are often marginalized in every realm of society because it's just made fun of. I think that a liberatory act then is to create a space for that to happen, or to counter the tendency to marginalize and dispossess people of traditional culture pieces.

Indeed, as Luke (2009) notes, when a school curriculum seeks to include indigenous, traditional, and migrant epistemologies from students' communities, it offers a socially just education.

\section{Understanding Academic Success at PCCS}

As I have demonstrated, PCCS adopts a resourceful perspective to diversity and guides students to critically analyze the sociopolitical contexts where they live. When talking about their academic success, many PCCS students attributed it to the caring teachers at PCCS who made their lives free of bullying and full of opportunities to learn about their own cultures and to acquire knowledge. Coupled with the fact that many PCCS teachers worked for long hours to ensure they provided quality education for the students, a better conceptualization of PCCS pedagogy is perhaps the one that sees "teaching as an act of love" (Darder, 2002). In exploring the legacy of Paulo Freire, Darder (2002) quoted the following from Freire (1998) to illustrate the revolutionary power of teaching as an act of love.

It is impossible to teach without the courage to love, without the courage to try a thousand times before giving in. In short it is impossible to teach without a forged, invented, and well-thought-out capacity to love. (p. 91)

PCCS teaching is best understood as a profound love for PCCS students and for the world. This deep love for the world helps PCCS teachers collaborate and struggle together to transform the public education that tends to oppress minority students.

Educated in a nurturing environment that encourages positive identification with their heritages and critical analysis of their lived experiences, PCCS students cultivate a strong sense of their identities and have good academic performance. This study adds evidence to the growing research on minority students' racial/ethnic identities and academic performance that indicates that stronger racial/ethnic identities are often related to better academic achievement among minority students. Many studies find that African American adolescents who hold a strong connection to, and pride in, being Black show more resilience in the face of challenges and demonstrate higher academic persistence (Altschul, Oyserman, \& Bybee, 2006). Similarly, recent research on immigrant students also highlights the fact that the maintenance of cultural 
traditions and connection to the ethnic community help immigrant youth persist in face of adversity (Portes \& Rumbaut, 2001; Portes \& Zhou, 1993).

PCCS students' academic success might also be related to the school's teaching of folk art and music in extended periods of time because it engages students in developing knowledge transferrable to other subject areas. Growing research on arts-based programs for youth, especially those that involve professionals, reveals that these programs touch upon similar skills that other subject areas demand (Heath, 2001, 2004; Heath \& Wolf, 2005). For example, both science and art projects demand attention to detail and understanding of specialized terms and processes, as well as analytical thinking. Teacher Eddie's proverb project exemplifies the integrative capacity of an arts project that generates other kinds of learning, including interviewing skills, compare-andcontrast skills for proverb analyses, and combinations of creative thinking and literacies. Similarly, when PCCS students worked on instruments with professional artists during their electives, they were actually engaged in a practice similar to what they were likely to encounter in lab experiments: they had extensive practice with tools under the direct guidance of a professional (cf., Heath \& Wolf, 2005).

\section{Conclusion}

This study examined how PCCS's vision of creating an equitable education for its diverse students is enacted and how students' identities are shaped by the school's vision and teaching. This paper has demonstrated that PCCS teaching and curriculum address issues related to cultural, linguistic, and racial diversity among its students and in the broader society. In general, PCCS adopts a resourceful perspective to diversity and often situates the discussion of diversity through a lens of social justice. Contrary to many schools that provide subtractive education to working-class students from diverse backgrounds (Valenzuela, 1999), PCCS teachers envision their students as social agents for change. Such innovative teaching seems to have a positive influence on minority students' identity development and academic performance. The findings presented above can contribute toward a better understanding of innovative teaching and learning for diverse students in the United States. This paper offers educators opportunities to ponder upon possibilities and creativity for educating students from diverse backgrounds. By revealing their voices and how educators can exert their agency to offer high quality education for all students, this work illustrates the urgency for educators to re-envision educational practices for all the students that they serve. 


\section{References}

Adair, J. K. (2010). Policy brief: Ethnographic knowledge for early childhood. Policy Brief prepared for the U.S. Department of Education's Office of Early Learning. ERIC: ED511898.

Alim, H. S. (2007). Critical Hip-Hop language pedagogies: Combat, consciousness, and the cultural politics of communication. Journal of Language, Identity, and Education, 6(2), 161-176.

Alim, H. S. (2010). Critical language awareness. In N. H. Hornberger \& S. L. McKay (Eds.), Sociolinguistics and language education (pp.205-231). Bristol, UK: Multilingual Matters.

Altschul, I., Oyserman, D., \& Bybee, D. (2006). Racial-ethnic identity in midadolescence: Content and change as predictors of academic achievement. Child Development, 77(5), 1155-1169.

Cookson, P., \& Berger, K. (2002). Expect miracles: Charter schools and the politics of hope and despair. Boulder, CO: Westview Press.

Crawford, J. (2000). At war with diversity: US language policy in an age of anxiety. Clevedon, UK: Multilingual Matters.

Creswell, J. W. (2013). Qualitative inquiry and research design: Choosing among five traditions (3rd ed.). Thousand Oaks, CA: Sage.

Darder, A. (2002). Reinventing Paulo Freire: A pedagogy of love. Cambridge, MA: Westview Press.

Darder, A. (2012). Cultural and power in the classroom: Educational foundations for the schooling of bicultural students. Boulder, CO: Paradigm Publishers.

Darder, A. (2014). Cultural hegemony, language, and the politics of forgetting: Interrogating restrictive language policies. In P. Orelus (Ed.), Affirming language diversity in schools and society: Beyond linguistic apartheid (pp. 35-53). New York, NY: Peter Lang.

Darder, A., Baltodano, M., \& Torres, R.D. (Eds.) (2003). The critical pedagogy reader. New York: NY, Routledge.

Faltis, C., \& Arias, M. B. (2013). Academic language in second language learning. Charlotte, NC: Information Age Publishing.

Finn, C. E., Manno, B. V., \& Vanourek, G. (2000). Charter schools in action: Renewing public education. Princeton, NJ: Princeton University Press.

Foley, D., \& Valenzuela, A. (2005). Critical ethnography: The politics of collaboration. In N. Denzin, \& Y. Lincoln (Eds.), The Sage handbook of qualitative research (3rd ed., pp. 217-234). Thousand Oaks, CA: Sage. 
Freire, P. (1998). Teachers as cultural workers: Letters to those who dare to teach. Boulder, CO: Westview.

Ginsberg, A. E. (2012). Courageous conversations: Teaching, cultural identity, and risk. In A. Ginsberg, Embracing risk in urban education: Curiosity, creativity, and courage in the era of "No Excuses" and relay race reform (pp. 61-81). Lanham, MD: Rowman \& Littlefield.

Giroux, H. A. (1989). Schooling for democracy. London, UK: Routledge.

González, N. (2005). Beyond culture: The hybridity of funds of knowledge. In N. González, L. Moll, \& C. Amanti (Eds.), Funds of knowledge: Theorizing practices in households, communities, and classrooms (pp. 29-46). Mahwah, NJ: Lawrence Erlbaum.

Heath, S. B. (1983). Ways with words: Language, life and work in communities and classrooms. New York, NY: Cambridge University Press.

Heath, S. B. (2001). There's not a crowd: Plans, roles, and focus in the arts. American Educational Research Association, 30(7), 10-17.

Heath, S. B. (2004). Learning language and strategic thinking through the arts. Reading Research Quarterly, 39(3), 338-342.

Heath, S. B., \& Wolf, S. (2005). Focus in creative learning: Drawing on art for language Development. Reading, 39(1), 38-45.

Herrell, A. (1999). Modeling talk to support comprehension in young children. Kindergarten Education: Research, Theory, and Practice, 3, 29-42.

Hirschman, C. (2001). The educational enrollment of immigrant youth: A test of the segmented-assimilation hypothesis. Demography, 28, 317-336.

Hornberger, N. H. (2009). Multilingual education policy and practice: Ten certainties (grounded in indigenous experience). Language Teaching, 42(2), 197-211.

Hull, G. (1993). Critical literacy and beyond: Lessons learned from students and workers in a vocational program and on the job. Anthropology and Education Quarterly, 24, 308-317.

James, C. E. (2012). Students "at risk": Stereotypes and the schooling of black boys. Urban Education, 47(2), 464-494.

Johnson, B. (2011). Comparing achievement between traditional public schools and charter schools within the big eight urban school districts in Ohio (doctoral dissertation). Retrieved from OhioLINK (Document No. miami1311693290).

King, J. B. (2004). Fulfilling the hope of Brown $v$ Board of Education through charter schools. In E. Rofes \& L. M. Stulberg (Eds.), The emancipatory promise of charter schools: Toward a progressive politics of school choice (pp. 55-75). Albany, NY: State University of New York Press.

Ladson-Billings, G. (1995). Toward a theory of culturally relevant pedagogy. American Educational Research Journal, 52(3), 465-491. 
Ladson-Billings, G. (2005). The evolving role of critical race theory in educational scholarship. Race, Ethnicity and Education, 8(1), 115-119.

Ladson-Billings, G. (2006). From the achievement gap to the education debt: Understanding achievement in U.S. schools. Educational Researcher, 35(7), 3-12.

Lee, S. J. (2005). Up against whiteness: Race, school, and immigrant youth. New York, NY: Teachers College Press.

Lubienski, C. (2003). Innovation in education markets: Theory and evidence on the impact of competition and choice in charter schools, American Educational Research Journal, 40(2), 395-443.

Lubienski, C. (2005). Public schools in marketized environments: Shifting incentives and unintended consequences of competition-based educational reforms, American Educational Research Journal, 111(4), 464-486.

Lucas, T., \& Villegas, A. M. (2010). The missing piece in teacher education: The preparation of linguistically responsive teachers. In C. Faltis \& G. Valdés (Eds.), Education, immigrant students, refugee students, and English learners: Yearbook of the National Society for the Study of Education (pp. 297-318). New York, NY: Teachers College Press.

Luke, A. (2009). Race and language as capital in school: A sociological template for language-education reform. In R. Kubota \& A. Lin (Eds.), Race, culture, and identities in second language education (pp. 286-308). New York, NY: Routledge.

Maxwell, J. (2013). Qualitative research design: An interactive approach (3rd ed.). Thousand Oaks, CA: Sage.

McLaren, P. (1989). Life in schools: An introduction to critical pedagogy in the foundations of education. New York, NY: Longman.

Miles, M. B., Huberman, M., \& Saldana, J. (2013). Qualitative data analysis: A methods resourcebook ( $3^{\text {rd }}$ ed.). Thousand Oaks, CA: Sage.

Milner, R. (2013). Rethinking achievement gap talk in urban education. Urban Education, 48(1), 3-8.

Moll, L., Amanti, C., Neff, D., \& González, N. (1992). Funds of knowledge for teaching: Using a qualitative approach to connect homes and classrooms. Theory into Practice, 31, 132-141.

Murphy, J., \& Shiffman, C. D. (2002). Understanding and assessing the charter school movement. New York, NY: Teachers College Press.

Nassaji, H. (2003). L2 Vocabulary learning from context: Strategies, knowledge sources, and their relationship with success in L2 lexical inferencing. TESOL Quarterly, 37(4), 645-670.

Nieto, S. (2003). What keeps teachers going? New York, NY: Teachers College Press. 
Ochs, E., \& Schieffelin, B. (2009). Language acquisition and socialization: Three developmental stories and their implications. In A. Duranti (Ed.) Linguistic anthropology: A reader (pp. 296-328). Boston, MA: Blackwell Publishing.

Paris, D. (2012). Culturally sustaining pedagogy: A needed change in stance, terminology, and practice. Educational Researcher, 41(3), 93-97.

Paris, D., \& Alim, S. (2014). What are we seeking to sustain through culturally sustaining pedagogy? A loving critique forward. Harvard Educational Review, 85-100.

Philips, S. (2009). Participant structures and communicative competence. Warm springs children in community and classroom. In A. Duranti (Ed.) Linguistic anthropology: A reader (pp. 329-342). Boston, MA: Blackwell Publishing.

Portes, A., \& Rumbaut, R. (2001). Legacies: The story of the immigrant second generation. Berkeley, CA: University of California Press.

Portes, A., \& Zhou, M. (1993). The new second generation: Segmented assimilation and its variants. Annals of the American Academy of Political and Social Sciences, 530, 74-96.

Reason, P. (2004). Critical design ethnography as action research. Anthropology and Education Quarterly, 35(2), 269-276.

Reyes, A. (2006). Language, identity, and stereotype among Southeast Asian American youth: The other Asian. New York, NY: Lawrence Erlbaum Associates.

Sleeter, C. (2012). Confronting the marginalization of culturally responsive pedagogy. Urban Education, 47(3), 562-584.

Thomas, J. (1993). Doing critical ethnography. Thousand Oaks, CA: Sage.

Tuan, M. (1998). Forever foreigners or honorary Whites?: The Asian ethnic experience today. New Brunswick, NJ: Rutgers University Press.

Valdés, G. (1996). Con respeto: Bridging the distances between culturally diverse families and schools: An ethnographic portrait. New York, NY: Teachers College Press.

Valenzuela, A. (1999). Subtractive schooling: US-Mexican youth in the politics of caring. Albany, NY: State University of New York Press.

Villegas, A. M., \& Lucas, T. (2011). Preparing classroom teachers for English language learners: The policy context. In T. Lucas (Ed.), Teacher preparation for linguistically diverse classrooms: A resource for teacher educators (pp. 35-52). New York, NY: Routledge.

Wei, D. (2007). Activist organization and parental engagement in Philadelphia's Chinatown. In L. S. Verplaetse, \& N. Migliacci (Eds.), Inclusive pedagogy for English language learners: A handbook of research-informed practices (pp. 225-242). New York, NY: Lawrence Erlbaum Associates.

Wink, J. (1997). Critical pedagogy: Notes from the real world. New York, NY: Longman. 
Wu, M-H., Lee, K., \& Leung, G. (2013). Heritage language education and investment among Asian American middle schoolers: Insights from a charter school. Language and Education, 28(1), 19-33. DOI:10.1080/ 09500782.2013 .763818

Yancey, P. (2004). Independent Black schools and the charter movement. In E. Rofes \& L. M. Stulberg (Eds.), The emancipatory promise of charter schools: Toward a progressive politics of school choice (pp. 125-157). Albany, NY: State University of New York Press.

Zimmer, R., Blanc, S., Gill, B., \& Christman, J. (2008). Evaluating the performance of Philadelphia's Charter schools. Working Paper. Rand Education. Retrieved from http://www.rand.org/pubs/working papers/ 2008/RAND WR550.pdf 